\title{
Pengembangan Perangkat Pembelajaran Matematika dengan Menggunakan Pendekatan Kontekstual pada Kelas $\mathrm{VII}_{2}$ SMP Negeri 26 Makassar
}

\author{
Munawarah \\ STAIN Watampone \\ e-mail:
}

\begin{abstract}
Abstrak
Penelitian ini adalah penelitian pengembangan (Research and Development) dengan ujicoba terbatas yang bertujuan untuk mengembangkan perangkat pembelajaran dengan pendekatan kontekstual pada pokok bahasan segitiga yang meliputi Buku Siswa, Lembar kegiatan Siswa, dan Rencana Pelaksanaan Pembelajaran. Subjek penelitian ini adalah siswa kelas VII 2 SMP Negeri 26 Makassar dengan jumlah mahasiswa sebanyak 36 orang. Prosedur pengembangan yang digunakan dalam penelitian ini adalah model Thiagarajan atau model 4-D (Define, Design, Develop, dan Dessiminate) yang meliputi 4 tahap, yaitu tahap pembatasan, tahap perancangan, tahap pengembangan, dan tahap penyebaran. Perangkat pembelajaran dengan pendekatan Kontekstual yang telah dikembangkan telah divalidasi dan mengalami revisi berulang-ulang kali sehingga didapatkan hasil yang maksimal dan layak untuk digunakan. Hasil dari ujicoba terbatas menunjukkan bahwa perangkat pembelajaran dengan pendekatan Kontekstual bersifat efektif dan praktis, yaitu (1) skor rata-rata yang diperoleh siswa pada tes haaasil belajar adalah 71,97 dari skor ideal 100 dengan standar deviasi 14,78. Di mana 29 dari 36 siswa atau 80,56\% memenuhi ketuntasan individuyang menunjukkan bahwa ketuntasan klasikal tercapai.; (2) dengan menggunakan perangkat pembelajaran dengan pendekatan kontekstual siswa jadi lebih aktif dalam proses pembelajaran; (3) pada umumya siswa memberikan respon yang positif terhadap perangkat pembelajaran yang digunakan; (4) guru dapat membimbing kelompok bekerja dan belajar; dan (5) tingkat kemampuan guru dalam mengelola proses pembelajaran dengan pendekatan Kontekstual termasuk dalam kategori tinggi, artinya penapilan guru dapat dipertahankan.
\end{abstract}

\section{PENDAHULUAN}

Perwujudan masyarakat yang berkualitas sesuai dengan visi misi reformasi pembangunan dalam rangka penyelamatan dan reformasi kehidupan nasional menjadi tanggung jawab pendidikan, terutama dalam mempersiapkan peserta didik menjadi subjek yang makin berperan menampilkan keunggulan dirinya yang tangguh, kreatif, mandiri, dan profesional dibidangnya masing-masing, karena ia merupakan model dasar bagi pembangunan manusia yang memiliki kualitas prima. Matematika merupakan ilmu universal yang mendasari perkembangan teknologi modern. Perkebangan pesat dibidang teknologi informasi dan komunikasi dewasa ini dilandasi oleh perkembangan matematika di bidang teori bilangan, aljabar, analisis, teori peluang, dan matematika diskrit. Untuk menguasai dan menciptakan teknologi di masa depan diperlukan penguasaan matematika yang kuat sejak dini. Mata pelajaran matematika perlu diberikan kepada semua peserta didik mulai dari sekolah dasar untuk membekali peserta didik dengan kemampuan 
JURNAL SAINTIFIK VOL.3 NO.1, JANUARI 2017

berpikir logis, analitis, sistematis, kritis dan kreatif, serta kemampuan bekerja sama. Selain itu, berdasarkan hasil penelitian menunjukkan bahwa pola pembelajaran di SMP cenderung "text book oriented" dan terkait dengan kehidupan sehari-hari siswa. Cara pembelajaran konsep cenderung abstrak dan mengunakan metode ceramah sehingga konsep-konsep akademik menjadi sulit dipahami oleh siswa. Kebanyakan guru mengajar dengan tidak memperhatikan kemampuan berpikir siswa atau dengan kata lain guru tidak melakukan pengajaran bermakna, akibatnya motivasi belajar siswa menjadi sulit ditumbuhkan dan pola belajar siswa cenderung menghafal (Direktorat SLTP, 2002).

Situasi tersebut mendorong dikembangkannya pemikiran bahwa pembelajaran matematika sebaiknya brsifat kontekstual, artinya pembelajaran matematika perlu dilaksanakan dengan menggunakan konteks tertentu, khususnya konteks dunia nyata sehingga bermakna bagi siswa manakala mereka meninggalkan sekolahnya. Namun disisi lain pada umumnya guru belum mampu membuat suatu perangkat matematika untuk digunakan dalam suatu pembelajaran matematika untuk digunakan dalam suatu pembelajaran, khususnya yang menggunakan pendekatan kontekstual. Pada umumnya penelitian pengembangan khususnya pengembangan perangkat pembelajaran ini masih jaran dilakukan di jenjang S1 dan perangkat-perangkat yang digunakan guru tidak melalui penelitian. Hal ini dapat dilihat dari belum mampunya guru membuat suatu perangkat pembelajaran matematika untuk digunakan dalam suatu pembelajaran, khususnya yang menggunakan pendekatan kontekstual. Berdasarkan uraian di atas maka peneliti termotivasi untuk megadakan penelitian dengan judul " Pengembangan Perangkat Pembelajaran Matematika dengan Menggunakan Pendekatan Kontekstual pada Kelas $\mathrm{VII}_{2}$ SMP Negeri 26 Makassar ".

\section{METODE PENELITIAN}

\section{Jenis Penelitian}

Jenis penelitian ini adalah penelitian pengembangan yang mengembangkan perangkat pembelajaran yang terdiri atas Buku Siswa, Rencana Pelaksanaan Pembelajaran, Lembar Kegiatan Siswa dan Tes Hasil Belajar.

\section{Lokasi dan Subjek Penelitian}

Penelitian ini dilaksanakan di SMP Negeri 26 Makassar tahun pelajaran 2007/2008, dan subjek penelitiannya adalah siswa kelas VII 2 dengan jumlah siswa 36 orang.

\section{Prosedur Penelitian}

Penelitian ini direncanakan akan dilaksanakan pada semester genap tahun pelajaran 2007/2008 dengan tiga tahap, yaitu tahap persiapan, pelaksanaan, dan tahap analisis data.

\section{Pengembangan Perangkat Pembelajaran Matematika}

Pengembangan perangkat pembelajaran matematika yang digunakan mengacu pada model 4-D Thiagarajan. Model ini merupakan sistem pendekatan pengembangan pembelajaran yang dilakukan meliputi 4 tahap, yaitu pembatasan, rancangan, pengembangan dan penyebaran. Pada tahap penyebaran belum dapat dilakukan dalam penelitian ini. Berikut adalah uraian secara rinci tahap-tahap pengembangan model 4-D yang digunakan dalam penelitian ini.

\section{Tahap Pembatasan}


Tujuannya adalah menetapkan dan menentukan syarat-syarat pembelajaran yang meliputi tujuan pembelajaran, dan pembatasan materi pembelajaran. Adapun langkah-langkahnya sebagai berikut.

\section{a. Analisis kurikulum tingkat satuan pendidikan}

Kurikulum ini memuat seperangkat rencana dan pengaturan mengenai tujuan, isi dan bahan pelajaran serta cara yang digunakan sebagai pedoman penyelenggaraan kegiatan pembelajaran untuk mencapai tujuan pendidikan di SMP dan dikembangkan berdasarkan prinsip bahwa peserta didik memiliki posisi sentral untuk mengembangkan kompetensinya agar menjadi manusia yang beriman dan bertakwa kepada Tuhan Yang Maha Esa, akhlak mulia, sehat, berilmu, cakap, kreatif, mandiri dan menjadi warga negara yang demokratis serta bertanggung jawab.

b. Analisis siswa

Analisis siswa merupakan telaah tentang karakteristik siswa yang sesuai dengan desain pengembangan perangkat pembelajaran. Karakteristik itu meliputi latar belakang kemampuan akademik (pengetahuan) dan perkembangan kognitif.

a. Analisis konsep

Analisis konsep digunakan untuk mengidentifikasi konsep-konsep utama yang akan diajarkan kemudian disusun secara sistematis konsep-konsep yang relevan.

a. Analisis tugas

Analisis tugas dilakukan dengan mengindentifikasi keterampilan-keterampilan utama yang diperlukan untuk merancang tugas-tugas yang harus dimiliki siswa setelah mengikuti pembelajaran.

b. Spesifikasi tujuan pembelajaran

Berdasarkan analisis konsep dan analisis tugas maka dalam kegiatan ini akan dirumuskan indikator pencapaian hasil belajar dengan mengacu pada kompetensi dasar. Perincian spesifikasi indikator hasil belajar merupakan acuan dalam merancang perangkat pembelajaran berbasis CTL.

2. Tahap Rancangan

Tujuannya adalah untuk menghasilkan rancangan perangkat pembelajaran dan tes hasil belajar siswa. Langkah-langkahnya adalah sebagi berikut:

a. Penyusunan tes

Berdasarkan analisis konsep dan analisis tugas, maka dapat disusun suatu tes yang akan menjadi instrumen pengumpul data tentang tingkat penguasaan siswa terhadap materi yang akan diajarkan.

\section{b. Pemilihan media}

Pemilihan media dalam penelitian ini disesuaikan dengan hasil analisis tugas, analisis konsep, $\mathrm{k}$ dan fasilitas yang ada di sekolah.

\section{c. Pemilihan format}

Pemilihan format dalam pengembangan perangkat pembelajaran dimaksudkan untuk mendesain atau merancang isi pembelajaran, pemilihan strategi, pendekatan, metode pembelajaran, dan sumber belajar yang dikembangkan.

\section{d. Perancangan awal perangkat pembelajaran}

Rancangan awal yang dimaksud adalah rancangan seluruh kegiatan yang harus dikerjakan sebelum ujicoba dilaksanakan. Adapun rancangan awal perangkat pembelajaran tersebut antara lain : Buku Siswa, Lembar Kegiatan Siswa (LKS), Rencana Pelaksanaan Pembelajaran (RPP), dan Tes Hasil Belajar (THB). Semua perangkat 
JURNAL SAINTIFIK VOL.3 NO.1, JANUARI 2017

pembelajaran yang dihasilkan pada tahap ini disebut dengan perangkat pembelajaran draft 1.

\section{Tahap Pengembangan}

Tujuan tahap pengembangan ini adalah untuk menghasilkan bentuk akhir perangkat pembelajaran setelah melalui revisi berdasarkan masukan para pakar ahli dan data hasil ujicoba. Langkah yang harus dilakukan pada tahap ini adalah sebagai berikut:

\section{a. Penilaian Para Ahli}

Langkah penafsiran ahli antara lain adalah validitas isi. Hal ini berarti validator menelaah semua perangkat pembelajaran yang telah dihasilkan (draft 1). Selanjutnya saran-saran dari para validator digunakan sebagai bahan pertimbangan dan landasan untuk melakukan revisi. Setelah perangkat draft 1 dilakukan perbaikan (revisi 1) maka diperoleh perangkat pembelajaran.

\section{b. Ujicoba Terbatas}

Perangkat pembelajaran yang telah direvisi yakni draft II, selanjutnya diujicobakan. Ujicoba hanya dilakukan pada satu keals saja, hal ini bertujuan untuk mendapatkan masukan langsung dari lapangan terhadap pembelajaran yang telah disusun. Hasil ujicoba dianalisis dan digunakan sebagai bahan pertimbangan untuk merevisi perangkat pembelajaran draft II. Perangkat pembelajaran yang didapat pada revisi ini adalah perangkat pembelajarn yang disebut draft III.

\section{Tahap Penyebaran}

Pada tahap ini penelitian belum dilaksanakan, hal ini karena pelaksanaannya hanya ujicoba terbatas saja.

\section{A. Pengembangan Instrument}

Untuk memperoleh informasi tentang aktivitas siswa dan guru selama kegiatan pembelajaran matematika dengan pendekatan kontekstual di kelas, maka perlu mengembangkan instrumen. Instrumen-instrumen itu adalah sebagai berikut.

1. Lembar pengamatan aktivitas siswa selama pembelajaran.

Instrumen ini digunakan untuk memperoleh data tentang aktivitas siswa selama proses pembelajaran dengan menggunakan pendekatan kontekstual.Informasi yang diperoleh melalui instrumen ini digunakan sebagai bahan pertimbangan untuk merevisi Buku Siswa, Lembar Kerja Siswa, Rencana Pelaksanaan Pembelajaran

2. Lembar pengamatan aktivitas guru selama pembelajaran.

Intrumen ini digunakan untuk memperoleh data tentang aktivitas guru selama proses pembelajaran berlangsung dengan menggunakan pendekatan kontekstual. Informasi yang diperoleh melalui instrumen ini digunakan sebagai bahan pertimbangan untuk merevisi Buku Siswa, LKS, RPP. Pengamatan aktivitas guru juga dilakukan oleh guru. Aktivitas guru meliputi mengiformasikan masalah yang harus dikerjakan bersama dalam kelompok, meminta siswa mengerjakan tugas LKS kelompok dengan kerjasama dalam kelompok, memberi arahan agar siswa selalu berada dalam tugas kelompok, meminta siswa mengerjakan tugas LKS, memberi pertanyaan yang merangsang berpikir siswa, memberi umpan balik dan kegiatan di luar tugas.

3. Lembar pengamatan pengelolaan pembelajaran matematika dengan pendekatan CTL. Intrumen ini digunakan untuk mengamati kemampuan guru dalam mengelola pmbelajaran dengan pendekatan CTL. Informasi yang diperoleh melalui instrumen ini digunakan untuk merevisi Rencana Pelaksanaan Pembelajaran. Pada lembaran ini, pengamat melakukan penilaian terhadap kemampuan mengelola pembelajaran dengan menggunakan tanda cek, pada baris dan kolom yang sesuai. 
4. Respon siswa terhadap kegiatan belajar

Respon siswa terhadap kegiatan pembelajaran matematika dengan pndekatan CTL diperoleh melalui angket. Digunakan untuk mengumpulkan informasi tentang respon siswa. Infomasi yang diperoleh melalui instrumen ini digunakan untuk merevisi Buku Siswa, dan LKS.

5. Tes hasil belajar

Tes hasil belajar digunakan untuk memperoleh informasi tentangpenguasaan siswa terhadap materi segitiga setelah pembelajaran berlangsung. Informasi yang diperoleh melalui instrumen ini digunakan untuk merevisi perangkat tes itu sendiri. Pemberian skor pada tes hasil siswa menggunakan skala bebas bergantung dari bobot soal.

\section{B. Desain Pengembangan Perangkat Pembelajaran}

Desain pengembangan perangkat pembelajaran dengan ujicoba terbatas digambarkan dengan diagram alir.
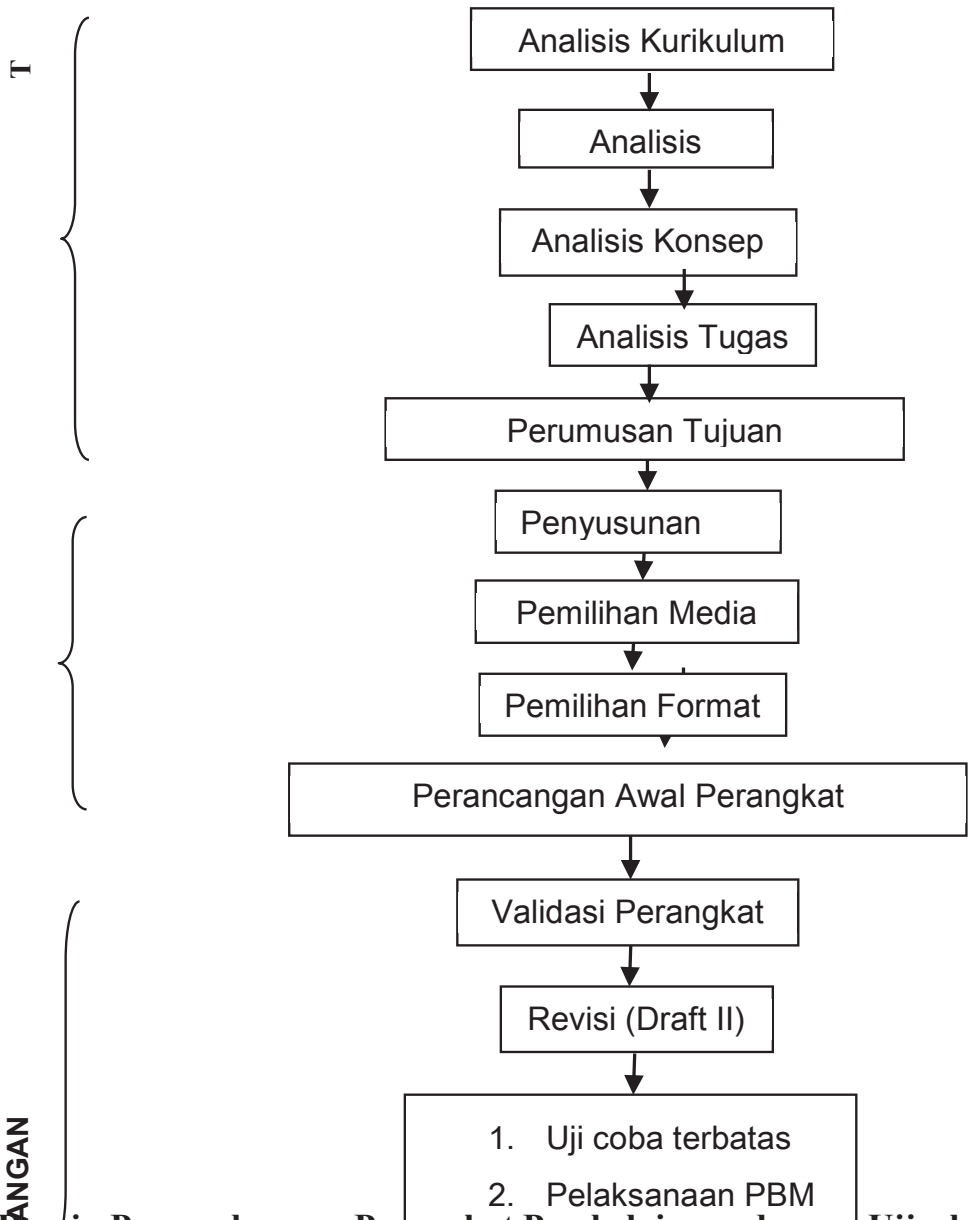

Diagram.

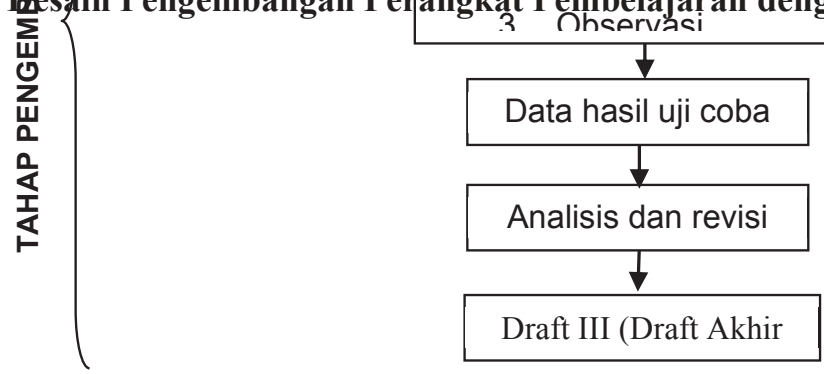


JURNAL SAINTIFIK VOL.3 NO.1, JANUARI 2017

\section{HASIL DAN PEMBAHASAN}

Perangkat pembelajaran matematika berbasis Contextual Teaching and Learning pada pokok bahasan segitiga yang telah divalidasi oleh para ahli dan telah diujicobakan akan dibahas pada bab ini. Pembahasan hasil penilaian oleh para ahli, pembahasan hasil aktivitas siswa dan kativitas guru serta hasil pengamatan pengelolaan pembelajaran dapat dijadikan sebagai bahan pertimbangan untuk mendapatkan draft akhir.

\section{Hasil Penelitian}

Prosedur pengembangan perangkat menggunakan model pengembangan dari Thiagarajan yang dikenal dengan model 4-D (four D models), dengan urutan tahapan pengembangan adalah tahap pembatasan, tahap perancangan, tahap pengembangan dan tahap penyebaran.

\section{Tahap Pembatasan}

a. Analisi kurikulum

Berdasarkan telaah terhadap pelaksanaan dan hasil pembelajaran matematika di SMP Negeri 26 Makassar adalah masih rendahnya prestasi belajar matematika yang dicapai oleh siswa selama ini. Proses pembelajaran lebih terfokus pada guru saja sementara siswa hanya mendengarkan dan mencatat apa yang disampaikan oleh guru.

b. Analisis siswa

Analisis siswa yang dilakukan meliputi analisis tentang latar belakang kemampuan akademik siswa dan perkembangan kognitif siswa. Dari hasil analisis tersebut diperoleh bahwa kemampuan berpikir siswa banyak dipengaruhi oleh situasi nyata sebagai bentuk pengalaman sehari-hari, sehingga mereka lebih termotivasi jika pembelajaran yang dilakukan menggunakan benda-benda nyata.

c. Analisis konsep

Materi pelajaran yang digunakan dalam penelitian ini adalah materi pokok bahasan segitiga untuk SMP kelas VII dengan mengacu pada kurikulum 2004.

d. Analisis tugas

Dalam analisis tugas berdasaran pokok bahasan segitiga diperoleh beberapa tugas-tugas yang diharapkan mampu mengarahkan kemampuan siswa untuk memahami materi pokok bahasan tersebut sehingga tujuan pembelajaran dapat tercapai.

e. Spesifikasi tujuan pembelajaran

Perician indikator dan tujuan pada materi segitiga adalah sebagai berikut:

- Mengenal jenis-jenis segitiga berdasarkan sisi dan sudutnya

- Mengenal sifat-sifat segitiga berdasarkan jenis-jenisnya

- Menunjukkan bahwa jumlah sudut segitiga adalah $180^{\circ}$

- Menghitung besar sudut dalam segitiga

- Menghitung keliling dan luas segitiga serta menggunakannya dalam pemecahan masalah.

\section{Deskripsi Tahap Rancangan}

- Penyusunan Tes

Berdasarkan analisis kurikulum, analisis siswa, analisis konsep dan analisis tugas yang telah dijelaskan pada tahap pembatasan selanjutnya disusun instrumen tentang tes kemampuan siswa dalam hal ini adalah tes hasil belajar siswa setelah mempelajari pokok bahasan segitiga.

- Pemilihan Media 
Media pembelajaran yang diperlukan dalam pelaksanaan matematika kontekstual pada materi pokok segitiga segitiga di kelas VII SMP adalah perangkat pembelajaran yang meliputi: RPP, BS, LKS, dan THB. Sedangkan alat bantu pelajaran yang meliputi: papan tulis, spidol, mistar, bususr, gunting, karton, penghapus, buku tulis, dan pulpen/pensil.

- Pemilihan Format

Format rencana pelaksanaan pembelajaran yang digunakan disesuaikan dengan format rencana pembelajaran dalam KTSP, sesuai dengan KTSP dalam rencana pelaksanaan pembelajaran tercantum standar kompetensi, kompetensi dasar, indikator, alokasinwaktu, tujuan pembelajarn, materi pembelajaran, strategi belajar mengajar, langkah-langkah kegiatan, alat dan sumber belajar, serta penilaian. Sedangkan format buu siswa dibuat bergambar sehingga siswa akan tertarik dan termotivasi untuk belajar

- Rancangan Awal

Kegiatan utama dalam tahap ini adalah penyususnan perangkat pembelajaran pokok bahasan segitiga untuk SMP kelas VII yang meliputi: Buku Siswa, LKS, RPP, THB. Pada tahap ini dihasilkan rancangan awal RPP untuk 3 kali pertemuan, Buku Siswa untuk setiap pertemuan, LKS untuk setiap pertemuan, dan THB beserta kisi-kisi dan kunci jawaban. Semua hasil ketiga perangkat pembelajaran pada tahap rancangan ini disebut sebagai Draft I (awal)

\section{Deskripsi Tahap Perancangan}

c. Penilaian ahli

Validasi ahli dilakukan untuk melihat semua perangkat pembelajaran yang diperoleh untuk mencakup vakiditas isi, bahasa, dan kesesuaian perangkat pembelajaran terhadap kurikulum yang berlaku. Hasil validitas ahli digunakan sebagai dasar untuk melakukan revisi dan penyempurnaan terhadap perangkat pembelajaran. Perangkat pembelajaran hasil revisi berdasarakan masukan dari para validator ini selanjutnya di uji cobakan pada siswa kelas $\mathrm{VII}_{2}$ SMP 26 Makassar. Kegiatan menilai perangkat pembelajaran diawali dengan memberikan perangkat pembelajaran beserta lembar penilaian kepada 2 orang ahli. Hasil penilaian, analisis, dan revisi terhadap perangkat pembelajaran tersebut dapat dijelaskan sebagai berikut:

\section{Hasil Penilaian terhadap Buku Siswa}

- Nilai rata-rata total kevalidan Buku Siswa yang diperoleh adalah 3,4. Dapat aspek, buku siswa ini dinyatakan memenuhi kriteria kevalidan.

- Nilai rata-rata kevalidan untuk aspek penjabaran konsep adalah 3,6. Dapat disimpulkan bahwa nilai ini termasukdalam kategori sangat valid. (memenuhi kriteria kevalidan)

- Nilai rata-rata kevalidan untuk aspek Konstruksi adalah 3,3 nilai ini termasuk dalam kategori valid

- Nilai rata-rata kevalidan untuk aspek karakteristik Subkonsep adalah 3,50 masuk dalam kategori sangat valid.

- Nilai rata-rata kevalidan untuk aspek soal-soal latihan adalah 3,2, dapat disimpulkan bahwa nilai termasuk dalam kategori Valid.

\section{Hasil Penilaian terhadap Lembar Kegiatan Siswa (LKS)}

- Nilai rata-rata total kevalidan LKSyang diperoleh adalah 3,3. Dapat disimpulkan bahwa nilai ini termasuk dalam kategori valid. Jadi ditinjau dari keseluruhan aspek. LKS ini dinyatakan memenuhi kriteria kevalidan. 
JURNAL SAINTIFIK VOL.3 NO.1, JANUARI 2017

- Nilai rata-rata kevalidan untuk aspek materi adalah 3,4. Dapat disimpulkan bahwa nilai ini termasuk dalam kategori valid. Jadi ditinjau dari keseluruhan aspek. LKS ini dinyatakan memenuhi kriteria kevalidan.

- Nilai rata-rata kevalidan untuk aspek aktivitas adalah 3,4. Dapat disimpulkan bahwa nilai ini termasuk dalam kategori valid. Jadi ditinjau dari keseluruhan aspek. LKS ini dinyatakan memenuhi kriteria kevalidan.

- Nilai rata-rata kevalidan untuk aspek bahasa adalah 3,4. Dapat disimpulkan bahwa nilai ini termasuk dalam kategori valid. Jadi ditinjau dari keseluruhan aspek. LKS ini dinyatakan memenuhi kriteria kevalidan.

- Nilai rata-rata kevalidan untuk aspek waktu adalah 3,00. Dapat disimpulkan bahwa nilai ini termasuk dalam kategori valid. Jadi ditinjau dari keseluruhan aspek. LKS ini dinyatakan memenuhi kriteria kevalidan.

\section{Hasil Penilaian terhadap Rencana Pelaksanaan Pembelajaran (RPP)}

- Nilai rata-rata total kevalidan Rencana Pelaksanaan Pembelajaran yang diperoleh adalah 3,36. Dapat disimpulkan bahwa nilai ini termasuk dalam kategori valid. Jadi ditinjau dari keseluruhan aspek. RPP ini dinyatakan memenuhi kriteria kevalidan.

- Nilai rata-rata kevalidan untuk aspek Tujuan adalah 3,4. Dapat disimpulkan bahwa nilai ini termasuk dalam kategori valid. Jadi ditinjau dari keseluruhan aspek. RPP ini dinyatakan memenuhi kriteria kevalidan.

- Nilai rata-rata kevalidan untuk aspek materi adalah 3,4. Dapat disimpulkan bahwa nilai ini termasuk dalam kategori valid. Jadi ditinjau dari keseluruhan aspek. RPP ini dinyatakan memenuhi kriteria kevalidan.

- Nilai rata-rata kevalidan untuk aspek sarana dan alat bantu pembelajaran adalah 3,5. Dapat disimpulkan bahwa nilai ini termasuk dalam kategori sangat valid. Jadi ditinjau dari keseluruhan aspek. RPP ini dinyatakan memenuhi kriteria kevalidan.

- Nilai rata-rata kevalidan untuk aspek metode dan kegiatan pembelajaran adalah 3,00. Dapat disimpulkan bahwa nilai ini termasuk dalam kategori valid. Jadi ditinjau dari keseluruhan aspek. RPP ini dinyatakan memenuhi kriteria kevalidan.

- Nilai rata-rata kevalidan untuk aspek waktu adalah 3,5. Dapat disimpulkan bahwa nilai ini termasuk dalam kategori sangat valid. Jadi ditinjau dari keseluruhan aspek. RPP ini dinyatakan memenuhi kriteria kevalidan.

Hasil Penilaian terhadap Tes Hasil Belajar (THB)

- Nilai rata-rata total kevalidan Tes Hasil Belajar yang diperoleh adalah 3,45. Dapat disimpulkan bahwa nilai ini termasuk dalam kategori sangat valid. Jadi ditinjau dari keseluruhan aspek. THB ini dinyatakan memenuhi kriteria kevalidan.

- Nilai rata-rata kevalidan untuk aspek Materi adalah 3,50. Dapat disimpulkan bahwa nilai ini termasuk dalam kategori sangat valid. Jadi ditinjau dari keseluruhan aspek. THB ini dinyatakan memenuhi kriteria kevalidan.

- Nilai rata-rata kevalidan untuk aspek Kontruksi adalah 3,30. Dapat disimpulkan bahwa nilai ini termasuk dalam kategori valid. Jadi ditinjau dari keseluruhan aspek. THB ini dinyatakan memenuhi kriteria kevalidan.

- Nilai rata-rata kevalidan untuk aspek bahasa adalah 3,30. Dapat disimpulkan bahwa nilai ini termasuk dalam kategori valid. Jadi ditinjau dari keseluruhan aspek. THB ini dinyatakan memenuhi kriteria kevalidan. 
- Nilai rata-rata kevalidan untuk aspek waktu adalah 3,50. Dapat disimpulkan bahwa nilai ini termasuk dalam kategori sangat valid. Jadi ditinjau dari keseluruhan aspek. THB ini dinyatakan memenuhi kriteria kevalidan.

Tabel. Rangkuman Hasil Validasi Perangkat Pembelajaran

\begin{tabular}{|l|c|c|}
\hline \multicolumn{1}{|c|}{ Sumber } & Skor Rata-rata Penilaian & Status \\
\hline Buku Siswa & 3,40 & $\mathrm{~V}$ \\
\hline Lembar Kegiatan Siswa & 3,30 & $\mathrm{~V}$ \\
\hline Rencana Pelaksanaan Pembelajaran & 3,36 & $\mathrm{~V}$ \\
\hline Tes Hasil Belajar & 3,45 & $\mathrm{~V}$ \\
\hline
\end{tabular}

Berdasarkan tabel di atas, dapat disimpulkan bahwa rata-rata penilaian atau hasil validasi dari para ahli pada perangkat pembelajaran yang dikembangkan yang meliputi Buku Siswa, LKS, RPP, dan Tes Hasil Belajar berada pada kategori "Valid" . hal ini berarti perangkat pembelajaran tersebut telah layak untuk diujicobakan.

\section{Analisis Deskriptif Hasil Penelitian}

Berdasarkan hasil ujicoba perangkat pembelajaran yang meliputi Buku Siswa, RPP, LKS, dan THB diperoleh data hasil tes belajar siswa, data hasil pengamatan aktivitas siswa, responsiswa terhadap kegiatan dan perangkat pembelajaran matematika dengan pendekatan CTL, data hasil pengamatan aktivitas guru, dan data hasil pengamatan pengelolaan pembelajaran matematika dengan pendekatan CTL. Data-data inilah yang digunakan untuk mengetahui kepraktisan, keefektifan perangkat pembelajaran matematika dengan pendekatan kontekstual. Hasil analisis masing-masing data sebagai berikut:

a. Hasil Belajar Siswa

Hasil analisis deskriptif secara kuantitatif penguasaan matematika setelah diberi tindakan pada tes hasil belajar dapat dilihat pada tabel berikut:

Tabel. Statistik skor hasil belajar matematika siswa kelas VII 2 SMP 26 Makassar

\begin{tabular}{|c|c|}
\hline Variabel & Nilai Statistik \\
\hline Subjek Penelitian & 36 \\
\hline Skor ideal & 100 \\
\hline Rata-rata & 71,97 \\
\hline Standar deviasi & 144,78 \\
\hline Varians & 218,428 \\
\hline
\end{tabular}




\section{JURNAL SAINTIFIK VOL.3 NO.1, JANUARI 2017}

\begin{tabular}{|c|c|}
\hline Rentang Skor & 65 \\
\hline Skor maksimum & 100 \\
\hline Jumlah siswa yang tuntas & 29 \\
\hline Jumlah siswa yang tidak tuntas & 7 \\
\hline
\end{tabular}

Distribusi Frekuensi dan Persentase Skor Hasil Belajar Matematika Siswa Kelas $\mathrm{VII}_{2}$ SMP Negeri 26 Makassar: dari 36 siswa yang mengikuti tes hasil belajar terdapat 8,33\% siswa masuk dalam kategori rendah, 25,00 siswa masuk dalam kategori sedang, 41,67 siswa masuk dalam kategori tinggi sedangkan siswa yang masuk dalam kategori sangat tinggi adalah $25 \%$. Hal ini menunjukkan bahwa siswa memperoleh pemahaman yang baik terhadap materi yang disajikan dengan menggunakan perangkat pembelajaran matematika dengan pndekatan kontekstual. Banyaknya siswa yang tuntas belajar atau yang mecapai ketuntasan individu yaitu siswa yang memperoleh skor 60-100 sebanyak 29 dari 36 orang siswa atau sekitar 80,565. Jadi banyaknya siswa yang belum tuntas sebanyak 7 orang atau sekitas 19,44\%. Data ini menunjukkan bahwa ketuntasan klasikal tercapai.

b. Aktivitas Siswa

Kategori aktivitas siswa:

\begin{tabular}{|c|c|}
\hline Kategori & Aktivitas Siswa \\
\hline 1 & Memperhatikan informasi dan mencatat seperlunya \\
\hline 2 & Membaca LKS, materi pembelajaran atau buku siswa \\
\hline 3 & Aktif terlibat dalam tugas \\
\hline 4 & Aktif berdiskusi dengan teman \\
\hline 5 & Mencatat apa yang disampaikan teman \\
\hline 6 & Mengajukan pertanyaan kepada teman/guru \\
\hline 7 & Menjawab, menanggapi pertanyaan teman/guru \\
\hline 8 & Memberi bantuan penjelasan kepada teman yang membutuhkan \\
\hline 9 & $\begin{array}{l}\text { Kegiatan di luar tugas, misalnya tidak memperhatikan penjelasan guru, } \\
\text { mengerjakan tugas mata pelajaran lain. Aktivitas lain yang tidak } \\
\text { berkaitan dengan KBM, misalnya tidur, ngantuk, melamun dan } \\
\text { sebagainya. }\end{array}$ \\
\hline
\end{tabular}

Berdasarkan data hasil analisis aktivitas siswa pada uji coba, dari 9 kategori yang diamati, ada 8 kategori terpenuhi (termasuk dalam batas interval yang dapat diterima). 


\section{c. Aktivitas Guru}

Data hasil pengamatan guru selama empat kali pertemuan selama proses pembelajaran sudah cukup baik.

d. Data hasil pengamatan pengelolaan pembelajaran matematika dengan pendekatan kontekstual.

Data hasil analisis pengamatan pengelolaan pembelajaran selama tiga kali pertemuan dapat di jelaskan sebagai berikut:

- Nilai rata-rata untuk fase mempersiapkan dan memotivasi siswa adalah 3,38, dapat disimpulkan bahwa nilai ini termasuk dalam kategori Tinggi, jadi dari fase mempersiapkan dan memotivasi siswa dalam pengelolaan pembelajaran dinyatakan baik.

- Nilai rata-rata untuk fase menyajikan informasi dan melibatkan siswa adalah 2,89, dapat disimpulkan bahwa nilai ini termasuk dalam kategori Tinggi, jadi dari fase menyajikan informasi dan melibatkan siswa dalam pengelolaan pembelajaran dinyatakan baik.

- Nilai rata-rata untuk fase mengorganisasikan siswa ke dalam kelompok belajar adalah 3,67, dapat disimpulkan bahwa nilai ini termasuk dalam kategori Sangat Tinggi, jadi dari fase mengorganisasikan siswa ke dalam kelompok belajar dalam pengelolaan pembelajaran dinyatakan baik.

- Nilai rata-rata untuk fase menyajikan informasi dan melibatkan siswa membimbing kelompok bekerja dengan belajar adalah 3,56, dapat disimpulkan bahwa nilai ini termasuk dalam kategori Sangat Tinggi, jadi dari fase menyajikan informasi dan melibatkan siswa dalam pengelolaan pembelajaran dinyatakan baik.

- Nilai rata-rata untuk fase diskusi dan negosiasi adalah 3,34, dapat disimpulkan bahwa nilai ini termasuk dalam kategori Tinggi, jadi dari fase menyajikan informasi dan melibatkan siswa dalam diskusi dan negosiasi dinyatakan baik.

- Nilai rata-rata untuk fase evaluasi dan penghargaan adalah 3,33, dapat disimpulkan bahwa nilai ini termasuk dalam kategori Tinggi, jadi dari fase evaluasi dan penghargaan dalam pengelolaan pembelajaran dinyatakan baik.

- Nilai rata-rata untuk kegiatan akhir adalah 2,75, dapat disimpulkan bahwa nilai ini termasuk dalam kategori Tinggi, jadi dari kegiatan akhir dalam pengelolaan pembelajaran dinyatakan baik.

- Nilai rata-rata untuk suasana kelas adalah 3,25, dapat disimpulkan bahwa nilai ini termasuk dalam kategori Tinggi, jadi ditinjau dari suasana kelas dalam pengelolaan pembelajaran dinyatakan baik.

Secara umum nilai rata-rata pengelolaan pembelajaran yang diperoleh adalah 3,27, dapat disimpulkan bahwa nilai ini termasuk dalam kategori Tinggi. Jadi ditinjau dari keseluruhan aspek pengelolaan pembelajaran matematika dengan pendekatan kontekstual berada pada kategori baik.

e. Respon siswa terhadap kegiatan pembelajaran matematika dengan pendekatan kontekstual

Respon siswa terhadap kegiatan pembelajaran matematika berdasarkan angket yang diberikan ke siswa sebagai berikut:

- Respon siswa tentang pembelajaran matematika 
JURNAL SAINTIFIK VOL.3 NO.1, JANUARI 2017

Sebagian besar siswa senang dengan pelajaran matematika. Mereka akan lebih senang lagi belajar matematika jika mereka berhasil memahami materi yang disajikan. Beberapa siswa juga menyatakan bahwa matematika itu kadang susah kadang mudah.

- Respon siswa terhadap Buku Siswa dan LKS

Pada umumnya siswa senang dengan LKS dan Buku Siswa yang digunakan. Beberapa siswa senang dengan LKS dan Buku Siswa yang digunakan karena penulisan dan gambarnya sangat mudah dimengerti.

- Respon siswa tentang pembelajaran matematika dengan pendekatan kontekstual Sebagian besar siswa berpendapat bahwa sangat bagus dan menyenangkan, karena mudah dimengerti penjelasan yang diberikan karena dapat dihubungkan dengan kehidupan nyata yang dialami sehari-hari.

Sehingga secara umum, perangkat-perangkat yang dikembangkan dapat dikatakan efektif karena terpenuhi 4 dari 5 kriteria, yaitu:

a. Hasil Belajar Siswa

Hasil belajar siswa memenuhi ketuntusan klasikal yaitu sebesar 80,6\% Lulus (syarat ketuntasan klasikal 75\%)

b. Aktivitas Siswa

Sembilan kategori pada aktivitas siswa terpenuhi

c. Aktivitas Guru

Dari delapan kategori pada aktivitas guru, semuanya terlaksana dengan baik pada setiap pertemuan.

d. Pengelolaan Pembelajaran

Dari hasil pengamatan pengelolaan pembelajaran matematika dengan pendekatan kontekstual tampak bahwa sebagian besar aspek dapat terlaksana dengan cukup baik dengan nilai rata-rata pngelolaan pembelajaran yang diperoleh adalah 3,27.

e. Respon Siswa

Minimal $50 \%$ respon siswa positif. Perangkat pembelajaran yang telah dikembangkan dikatakan efektif apabila memenuhi 3 dari 4 indikator, etapi indikator 1 harus terpenuhi. Berdasarkan hasil penelitian diperoleh informasi bahwa semua indikator tersebut di atas terpenuhi. Oleh karena itu, perangkat pembelajaran matematika yang dikembangkan dengan menggunakan pendekatan kontekstual yang meliputi Buku Siswa, Lembar Kerja Siswa, Rencana Pelaksanaan Pembelajaran, dan Tes Hasil Belajar dinyatakan efektif dan layak digunakan.

\section{KESIMPULAN}

1. Penelitian yang dilakukan adalah penelitian pengembangan perangkat pembelajaran pada pokok bahasan segitiga dengan pendekatan kontekstual yang terdiri dari empat tahap yaitu: (a) tahap pembatasan (define), tahap perancangan (design), tahap pengembangan (develop), dan tahap penyebaran (dessiminate).

2. Setelah dilakukan validasi dan revisi sebanyak 2 kali, perangkat pembelajaran yang meliputi Buku Siswa, LKS, RPP, THB dinyatakan valid dan layak untuk digunakan berdasarkan hasil penilaian para ahli 


\section{JURNAL SAINTIFIK VOL 3 NO.1, JANUARI 2017}

3. Hasil uji coba perangkat pembelajaran matematika dengan pendekatan kontekstual menunjukkan bahwa:

- Skor rata-rata yang diperoleh siswa pada tes hasil belajar adalah 71,97 dari skor ideal 100 dengan standar deviasi 14,78

- Penggunaan perangkat pembelajaran matematika dengan pendekatan kontekstual dapat menciptakan kondisi yang kondusif yang memungkinkan siswa belajar aktif selama proses pembelajaran

- Banyaknya siswa yang tuntas belajar adalah 29 dari 36 orang $(80,56 \%)$

- Guru mampu mengelola proses pembelajaran dengan menggunakan pendekatan kontekstual.

\section{DAFTAR PUSTAKA}

Darwis, Muhammad. 2007. Model Pembelajaran Matematika yang Melibatkan Kecerdasan emosional. Disertasi Program Pascasarjana Program studi Pendidikan Matematika Universitas Negeri Surabaya. Tidak diterbitkan.

Dimiyanti; Moedjiono. 1994. Belajar dan Pembelajaran.Jakarta: Depdikbud.

Hadis, Abdul. 2006. Psikologi dalam Pendidikan. Bandung: Alfabeta

Hamalik, O.2005. Kurikulum dan Pembelajaran. Jakarta: Bumi Aksara

Jumriati. 2006. Pengembangan Perangkat Pembelajaran Matematika Berbasis Contextual Teaching and Learning. Skripsi FMIPA UNM Makassar. Tidak Diterbitkan.

Mulyasa. 2006. Kurikulum yang Disempurnakan. Bandung: Remaja Rosdakarya.

Subaer. 2005. Research \& Develpmen $(R \& D)$. Eksponen Jurnal Pendidikan Matematika, Januari 2005 FMIPA UNM

Upu, Hamzah. 2005. Karakteristik Research and Development (R \& D). Eksponen Jurnal Pendidikan Matematika dan Matematika Edisi Khusus, Januari 2005 FMIPA UNM 